\title{
Epithelial Stem Cells of the Prostate and Their Role in Cancer Progression
}

\author{
R.U. LUKACS, ${ }^{*}$ D.A. LAWSON, ${ }^{*}$ L. XIN,${ }^{\ddagger}$ Y. ZONG,${ }^{\dagger}$ I. GaRRAWAY,, \\ A.S. Goldstein, ${ }^{\varepsilon}$ S. Memarzadeh, ${ }^{\#}$ and O.N. WitTe ${ }^{*}+\varepsilon \& \Delta$ \\ *Department of Microbiology, Immunology, and Molecular Genetics, University of California, Los Angeles; \\ ${ }^{*}$ Department of Molecular and Cellular Biology, Baylor College of Medicine; ${ }^{\dagger}$ Howard Hughes Medical \\ Institute at UCLA; "Department of Urology, David Geffen School of Medicine at UCLA; 'Molecular Biology \\ Institute, " Department of Obstetrics and Gynecology, ${ }^{\S}$ Broad Stem Cell Research Center at UCLA; \\ ${ }^{\Delta}$ Department of Molecular and Medical Pharmacology, David Geffen School of Medicine, University \\ of California, Los Angeles, California 90095
}

\begin{abstract}
Prostate cancer is a leading cause of cancer-related death in adult men. It can regress dramatically upon antihormonal therapy, but it often recurs in a more aggressive, androgen-independent form. Defining the prostate tissue stem cells (PrSCs) and their involvement in cancer initiation and maintenance may lead to better therapeutics. Using a tissue-regeneration model in which dissociated prostate epithelial cells mixed with inductive mesenchyme give rise to prostatic tubules, we have identified a small population of prostate cells that contains multiple stem cell characteristics. In this system, prostate cancer can be initiated by autocrine or paracrine growth factor signaling and intracellular overexpression of genes often found mutated in human prostate cancer. Using an in vitro prostate sphere assay, we further defined the PrSC population and demonstrated their selfrenewal and multilineage differentiation capabilities. Microarray analyses of the stem- and non-stem-cell populations have assisted us in finding and evaluating additional markers that can better define the PrSC population and further delineate the different cell types of the prostate, including those that serve as the target cell for tumor initiation.
\end{abstract}

Death rates from some leukemias, Hodgkin's disease, and testicular cancer have decreased significantly during past decades due to dramatic advances in their treatments. Although there have been improvements in prevention and early detection for the most common epithelial malignancies, there has not been significant improvement in the survival of patients with metastatic disease. It is widely accepted that transformation is caused by genetic changes leading to alterations in growth regulatory functions. New genome-wide screening methods have identified many of these potential oncogenes and tumor-specific mutations to target therapeutically. However, the fundamental question remains: Are we targeting the right cells?

Adult stem cells have the unique capability to selfrenew and persist throughout a person's life span while retaining the potential to differentiate into any mature cell type of the tissue. Such mammalian tissue stem cells were first defined in the hematopoietic system but have since been identified in many solid organs as well, including the prostate (Till and McCulloch 1961; Isaacs 1987; Lois and Alvarez-Buylla 1993; Blanpain et al. 2007). The idea that primitive cells and cancer cells are related was postulated more than 150 years ago, when Rudolf Virchow (1855) noticed a histologic resemblance of teratocarcinomas to tissues of the developing fetus. Mounting evidence from more current studies suggests that stem cells and early progenitors are likely involved in cancer initiation as the cell of origin or in tumor maintenance acting as cancer stem cells.

Studies in leukemia suggest that some cell types may be more prone to transformation than others (Cozzio et al. 2003; Huntly et al. 2004). The theory that stem cells are the "cells of origin" for cancer is supported by their long- lived nature, which allows for multiple mutations to accumulate over time. Studies in blood and solid tissue cancers that show that stem cell pathways are present and often overactivated in tumors further support this belief (Reya et al. 2001). An alternate theory is that a mutated progenitor or differentiated cell can exploit and reactivate normal self-renewal pathways during carcinogenesis, potentially becoming the "cancer stem cell" (CSC) that maintains the tumor (Jamieson et al. 2004; Wicha et al. 2006). The idea of CSCs arose in the 1960s when two groups hypothesized that cancers are composed of a heterogeneous population of cells with different capacities for tumor propagation (Bruce and Van Der Gaag 1963; Southam et al. 1969). This theory is supported by studies in which distinct populations of cells isolated from acute myeloid leukemia (AML) $\left(\mathrm{Lin}^{-} \mathrm{CD} 34^{+} \mathrm{CD} 38^{-}\right)$, brain tumors $\left(\mathrm{CD} 133^{+}\right)$, and breast cancers ( $\mathrm{Lin}^{-} \mathrm{CD} 44^{+} \mathrm{CD} 24^{-/ / \mathrm{lo}}$ ) were shown to contain all of the tumorigenic activity in their respective cancers (Bonnet and Dick 1997; Al-Hajj et al. 2003; Singh et al. 2004).

The CSC theory is an appealing concept based on elegantly designed experiments, but there are still many uncertainties, both theoretical and technical, about the interpretations of the data. Serial tumor transplantation experiments are the gold standard to measure the activity of cancer stem cells. However, it has been demonstrated that the growth of secondary tumors is highly dependent on the environment to which the cells are exposed. Factors such as the location of the transplantation, the presence or absence of highly irradiated feeder cells, and the inclusion of additional extracellular matrix components significantly affect the growth potential of implanted tumor cells (Hewitt et al. 1973; Peters and Hewitt 1974; Hill 2006). 
Prostate cancer is the most commonly diagnosed cancer and the second highest cancer-related cause of death among men. The most frequently used treatment, androgen ablation, is based on the fact that the majority of prostate cancer cells are hormone-dependent (Huggins and Hodges 1941). This is a successful treatment initially, but the disease often recurs in an aggressive, androgenindependent form that is extremely difficult to treat. In the normal organ, androgen withdrawal through chemical or surgical castration causes approximately $90 \%$ of the differentiated cells to apoptose, leaving the primitive cell populations unaffected (Kyprianou and Isaacs 1988). This observation has led people to hypothesize that the subpopulation of remaining cancer cells after androgen ablation contains these primitive cells that can potentially cause the recurrence of the disease (Litvinov et al. 2003). Investigation of the potential roles of PrSCs in cancer initiation and maintenance may lead to more successful treatments for the disease.

\section{THE PROSTATE GLAND AND ADULT PROSTATE STEM CELLS}

The prostate is located at the base of the bladder in males, surrounding the urethra (Cunha et al. 1987). The gland is composed of tubules that have an epithelial compartment surrounded by stromal cells that include fibroblasts, smooth muscle, and myofibroblasts. The epithelium consists of two cellular compartments made up of three morphologically, functionally, and molecularly distinct cell types. Androgen-independent flat basal cells are attached to the basement membrane, where they maintain the homeostasis of the organ and express the high-molecular-weight cytokeratins (CK)5 and CK14. A subpopulation of basal cells also expresses the p53-family-related gene $p 63$. Neuroendocrine cells reside largely in the basal compartment, where they secrete neuroendocrine peptides such as synaptophysin and chromogranin A that support epithelial viability (Bonkhoff 1998; Abrahamsson 1999). Luminal cells are CK8/18positive androgen-dependent columnar cells that lay above the basal layer facing the lumen of each tubule, where they secrete prostatic proteins. Several groups have also reported a fourth population of epithelial cells, named transit-amplifying cells, that coexpress basal (CK5) and luminal (CK8) markers (Isaacs and Coffey 1989), as well as prostate stem cell antigen (PSCA) in later stages (Tran et al. 2002).

There are conflicting views of the lineage hierarchy of the prostate and the relationship among the different cell types. The existence of PrSCs was determined by the observation that the rodent prostate can undergo up to 30 cycles of involution and regeneration in response to androgen cycling (English et al. 1987). Two prevalent models have emerged to explain how these PrSCs give rise to the different cell types of the prostate. The linear model proposes that the PrSCs reside among the CK5positive basal cells, where they can differentiate into the double-positive intermediate/transit-amplifying population and then finally into the CK8-positive luminal phenotype (Fig. 1A) (Isaacs and Coffey 1989; Hudson et al.
2001). This is partially based on the preferential survival of basal cells after castration and their ability to repopulate the luminal compartment upon androgen add-back (Isaacs 1987; Bonkhoff and Remberger 1996). In vitro studies have also shown that $\mathrm{PSCA}^{-}$basal cells can give rise to $\mathrm{PSCA}^{+}$intermediate cells coexpressing basal and luminal cytokeratins (Tran et al. 2002) that can differentiate into luminal cells (Hudson et al. 2000; Xin et al. 2007). Other investigators have proposed a branched model of differentiation where the luminal and basal cells are in separate lineages, maintained by separate progenitor cells (Fig. 1B). This model is supported by observations that after castration, residual quiescent luminal cells remain in the rodent prostate that have high proliferative activity upon androgen add-back (Evans and Chandler 1987; Tsujimura et al. 2002). Immunohistochemical (IHC) studies have also shown that fetal and prepubertal human epithelia appear positive for all cytokeratins, and no intermediate phenotype was seen in situ (Wernert et al. 1987; Wang et al. 2001). In this model, the PrSCs lose CK5/14 or CK8/18 as they differentiate into committed progenitors and then luminal or basal cells, respectively.

Several theories exist for the origin of the neuroendocrine cells as well. Due to their location among the basal cells during development and adulthood, and their expression of basal cell cytokeratins, many believe that neuroendocrine cells are derived from the PrSCs or basal cells (Fig. 1B) (Kellokumpu-Lehtinen et al. 1979; Bonkhoff and Remberger 1996). Other investigators have suggested that these cells are derived from neural crest cells, because they secrete neuropeptides such as sero-

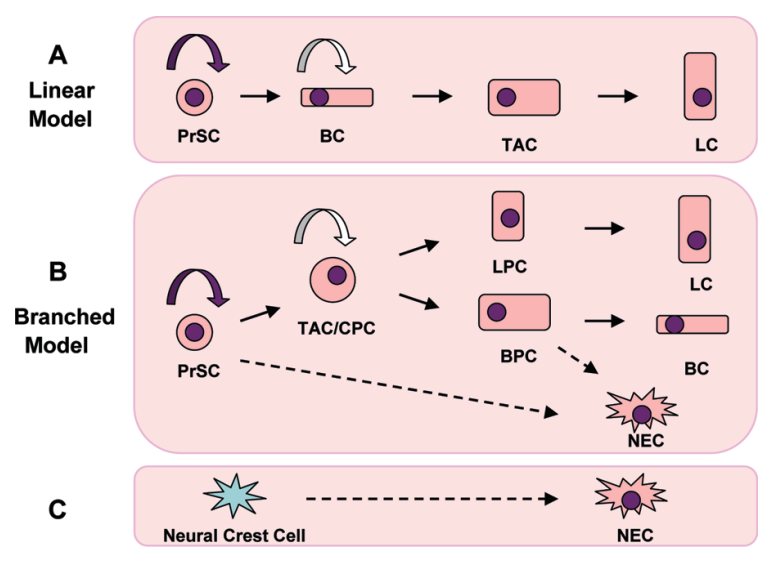

Figure 1. Models of prostate lineage hierarchy. (A) Schematic representation of the linear model of prostate differentiation where the basal, transit-amplifying, and luminal cells are in the same lineage. $(B)$ Schematic representation of the branched model of prostate differentiation where the basal, luminal, and neuroendocrine cells are in separate lineages, but they are originally derived from one common stem cell. (C) An alternate theory for the origin of the prostate neuroendocrine cells suggests that they are derived from neural crest cells. (BC) Basal cell; (BPC) basal progenitor cell; (CPC) common progenitor cell; (LC) luminal cell; (LPC) luminal progenitor cell; (NEC) neuroendocrine cell; (TAC) transit-amplifying cell. (Burgundy curved block arrow) Self-renewal; (white curved block arrow) limited self-renewal. 
tonin, thyroid-stimulating hormone (TSH)-like polypeptide, and somatostatin (Fig. 1C) (Aumuller et al. 1999). To study the PrSCs and better define their differentiation mechanism, recent efforts have focused on the development of efficient in vitro and in vivo assays.

\section{APPROACHES FOR STUDYING PROSTATE STEM CELLS}

Assays have been developed to grow multipotent cells outside their natural settings to identify stem-cell-specific markers for isolation, maintain their growth, and study their biology. Studies in the hematopoietic field have pioneered stem cell assay development, starting with the first demonstration of in vivo transplantation of hematopoietic stem cells (HSCs) into lethally irradiated mice and the first clonal growth of bone marrow cells in vitro (Ford et al. 1956; McCulloch and Till 1960; Bradley and Metcalf 1966). Many current neural and epithelial stem cell assays have been derived and adapted from these original methods.

\section{In Vitro Colony-forming Unit Assay}

Short-term in vitro assays are often preferred for studying differentiation and preliminary quantification of marker-based stem cell enrichments. Limiting dilution assays were used to measure frequencies of different hematopoietic cell subsets as they grew underneath a stromal layer as cobblestone area-forming cells (Ploemacher et al. 1989). Mammary and neural tissues can be cultured on solid substrate where they undergo differentiation in a hormone-, growth-factor-, or cell-cell interaction-regulated process (Reynolds and Weiss 1996; Dontu et al. 2003). Some of these methods were combined to develop in vitro prostate colony-forming unit (cfu) assays, in which dissociated adult prostate epithelial cells form colonies on top of feeder cells (Hudson et al. 2000; Uzgare et al. 2004; Lawson et al. 2007).

Primary mouse prostate cells have a colony-forming activity of 1 in 1000. Cells from castrated mice have a significant growth advantage over those from intact mice, indicating that stem or progenitor cells contribute to colony formation (Lawson et al. 2007). Mixing experiments using wild-type and transgenic green fluorescent protein (GFP) and Discosoma sp. red fluorescent protein (dsRed) prostate cells produce monochromatic colonies, suggesting that they are clonally derived. The majority of cells coexpress CK5 and CK8, indicating that they have an intermediate/transit-amplifying phenotype. One possibility for this observation is that the intermediate cells rather than the PrSCs from the prostate are responsible for giving rise to these colonies. Another explanation is that PrSCs give rise to the colonies, but without the proper niche signals, they differentiate into the intermediate phenotype. These colonies do not passage efficiently (Fig. 2A), further indicating that this assay promotes differentiation. Hudson et al. (2000) reported that two types of colonies can grow from primary human prostate cells: type I intermediate colonies and rare type II primitive basal cell colonies, suggesting that both stem and progenitor cells can thrive in this culture. These findings demonstrate that this assay could be used to quantitatively compare stem and progenitor cell enrichment techniques, but not to maintain them over time.

\section{In Vitro Sphere Assay}

A major advance in adult stem cell research was achieved by the discovery that undifferentiated multipotent neural cells can be grown and maintained in suspension using the neurosphere assay (Reynolds and Weiss 1996). Similar culture systems were developed for mammary stem cells, where it was shown that mammospheres can be serially passaged to demonstrate self-renewal activity in vitro (Dontu et al. 2003). Primary mouse prostate cells can also be maintained and passaged under floating conditions (Shi et al. 2007) where they exhibit increased expression of putative stem cell markers. To further replicate the stem cells' natural environment, a cell-matrix interaction component has also been introduced to this assay. Human prostate cancer cell lines and immortalized lines of normal cells can form spheroids in a semisolid matrix called Matrigel (Webber et al. 1997; Bello-DeOcampo et al. 2001; Lang et al. 2001). We have recently shown that a small fraction of primary prostate cells ( 1 in 1000) can also give rise to clonally derived spheres in Matrigel (Xin et al. 2007).

These spheres spontaneously develop a lineage hierarchy with the more immature $\mathrm{p} 63^{+}$basal cells localized to the outer rim and the PSCA $^{+}$transient-amplifying cells growing near the center. Sphere cells can be driven to terminal differentiation when allowed to adhere to a substratum and treated with testosterone, suggesting that the sphere-forming cells are multipotent. Spheres can be serially passaged for up to 12 generations, demonstrating their self-renewal activity in vitro (Fig. 2B). Dissociated cells from spheres can also be implanted in vivo to regenerate tubules containing both basal and luminal cells. This regeneration occurs at a low efficiency, suggesting that a part of the niche signaling is missing from the culture or that the spheres expand a progenitor population with less regenerative capacity.

\section{In Vivo Regeneration Assay}

Powerful in vivo engraftment and regeneration assays have been developed to characterize tissue stem cells from the blood (Harrison 1980) and the breast (Kordon and Smith 1998). The essence of these assays is that cells are put back into their natural environment already containing the appropriate structure and supportive stroma. Because the prostate cannot easily be cleared of epithelial cells, Cunha and Lung (1978) developed a prostate tissue fragment recombination assay that has been used to study prostate development and epithelial-mesenchymal interactions. In this procedure, fragments of rodent urogenital sinus mesenchyme (UGSM) are combined with adult prostate epithelial fragments and implanted under the kidney capsule of an immunodeficient mouse to generate prostatic tubules.

To use this assay for quantitative stem cell enrichment experiments, we modified the system to use single-celldissociated epithelial and UGSM cell preparations (Xin et 


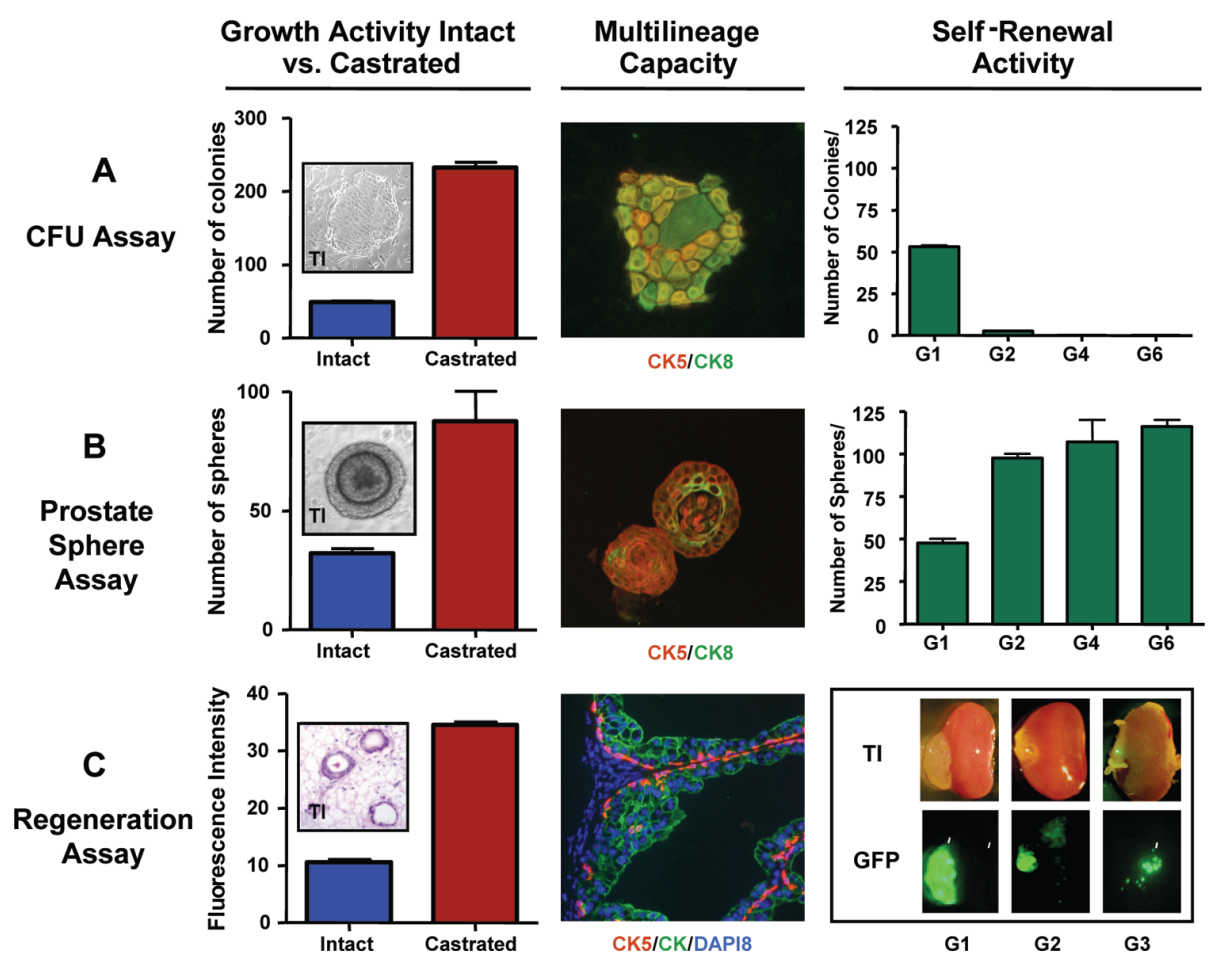

Figure 2. Summary of the prostate epithelial cell assays. $(A)$ Graph represents the number of colonies that were formed after $5 \times 10 \mathrm{e} 4$ prostate cells from castrated and intact C57BL/6 mice were plated on top of irradiated 3T3 cells in the cfu assay. Transillumination image (TI) shows a representative colony (left). Immunofluorescence stains show that colonies coexpress the luminal (CK8) and basal (CK5) cytokeratins (middle). Generation 1 (G1) colonies were dissociated and $5 \times 10 \mathrm{e} 4$ cells were replated to test self-renewal. Rare colonies formed in generation $2(\mathrm{G} 2)$, but did not passage further (right panel). (B) Graph represents the number of spheres that grew after $5 \times 10 \mathrm{e} 4$ prostate cells from castrated and intact C57BL/6 mice were plated into Matrigel. TI image shows a representative sphere (left). Immunofluorescent image shows that the outer cells in spheres are CK5-positive, whereas the inner cells coexpress CK5 and CK8 (middle). Generation 1 (G1) spheres were dissociated and serially replated in equal numbers $(5 \times 10 \mathrm{e} 4)$ for several generations (G2-G6) to test self-renewal (right). (C) Equal numbers $(2 \times 10 \mathrm{e} 5)$ of prostate cells from castrated and intact transgenic mice harboring $\beta$-actin-driven GFPs were engrafted under the kidney capsule of SCID mice. Grafts were harvested after 8 weeks and the fluorescence intensities (x 10e6) of GFP signals were quantified by a CCD camera (left). Immunofluorescence staining shows CK5-positive cells located in the outer layer of the tubules and CK8-positive luminal cells facing the lumen (middle). Primary grafts were generated from $2 \times 10 \mathrm{e} 5$ transgenic $\mathrm{GFP}^{+}$cells plus $2 \times 10 \mathrm{e} 5 \mathrm{UGSM}$ cells. After 8 weeks of regeneration, grafts were dissociated, and $2 \times 10 \mathrm{e} 5$ cells were combined with fresh UGSM and transplanted into secondary and then tertiary recipients to show self-renewal in vivo. Transillumination (TI) and fluorescent (GFP) images show the grafts from generations 1, 2, and 3 (right).

al. 2003). Like Cunha's assay, the prostatic tubules derived from dissociated cell preparations display the same cellular composition as normal prostate tubules. Serial dilution experiments combining decreasing numbers of dissociated $\mathrm{GFP}^{+}$prostate cells with noncolored wild-type cells revealed an average tubule-forming activity of approximately 1 in 2500 . This number is lower than the 1 in $1000 \mathrm{cfu}$ and sfu (sphere-forming unit) activity seen in the colony and sphere assays. The inconsistency could be an indicator that in addition to stem cells, progenitor cells can also give rise to colonies and spheres in vitro, whereas they cannot form tubules in vivo.

Mixing experiments produce only monochromatic tubules, suggesting that they are also clonally derived (Azuma et al. 2005; Xin et al. 2005). IHC analysis of these prostatic grafts reveals both CK5-positive basal cells in the outer layer of most tubules and CK8-positive luminal cells in the inner regions (Fig. 2C). Because all of the tubules are clonal, one can deduce that the cells giving rise to these ducts are multipotent. Comparison of the regeneration activity of cells from castrated versus intact mice shows that the stem-cell-enriched fractions have higher growth capacity, just like in the in vitro assays (Fig. 2C) (D. Lawson, unpubl.).

Self-renewal activity has been demonstrated in HSCs (Lemischka et al. 1986) and mammary stem cells (Kordon and Smith 1998) using in vivo serial transplantation experiments. We took two different approaches to study PrSC self-renewal in our regeneration assay. Grafts generated from dissociated $\mathrm{GFP}^{+}$prostate cells were harvested from primary recipients, dissociated into single cells, combined with fresh UGSM, and retransplanted into secondary and then tertiary recipients. Tubule formation was seen in all of the grafts, but the growth activity seemed to decrease with every passage (Fig. 2C). In a similar approach used to compare the in vivo self-renewal activity of the proximal versus distal prostate, Lynette Wilson's group saw more persistent self-renewal activity in cells from the proximal region, but they also observed a decrease in tubule formation over four rounds of trans- 
plantation (Goto et al. 2006). This decline could be interpreted as evidence that the cells giving rise to tubules do not have long-term self-renewal, but more likely, it is due to the technical shortcomings of this method.

In our second approach, we took advantage of the ability of the prostate to involute and regrow in the absence and presence of androgen. Dissociated cells from mice harboring a prostate-specific probasin promoter-driven luciferase (Pb-Luc) transgene (Xie et al. 2004) were used in our regeneration assay to allow visualization of the grafts throughout the experiment (Fig. 3A). The mice were imaged after 6 weeks using a charge-coupled device (CCD) camera to reveal a bright signal representing the outgrowth of the prostatic graft. The mice were then subjected to two rounds of androgen cycling, with CCD images taken at every involution and regrowth phase. The images show a cyclic decrease and increase in signal corresponding to the absence/presence of androgen (Fig. 3B). From sample mice taken at each stage, we confirmed that after androgen ablation, grafts had involuted and the luminal cells had undergone apoptosis, and after each regrowth, the tubules reformed to contain new luminal cells. This approach proves to be a unique alternative tool for the study of PrSC self-renewal in vivo.

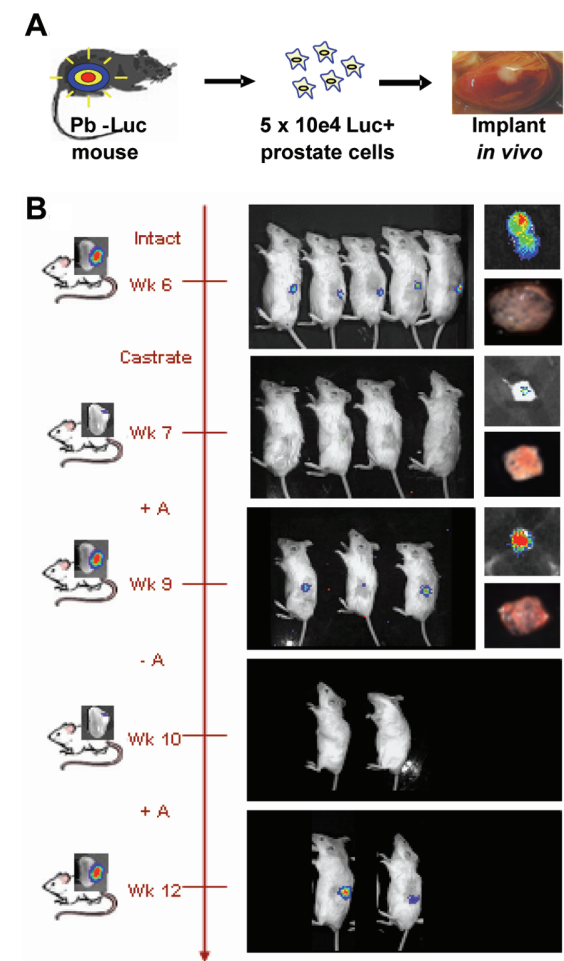

Figure 3. Development of in vivo prostate self-renewal assay. (A) Cells were dissociated from 8 -week-old $\mathrm{Pb}$-Luc mouse prostates; $5 \times 10$ e 4 cells were combined with $1 \times 10 \mathrm{e} 5 \mathrm{UGSM}$ cells and implanted under the kidney capsule of SCID mice. $(B)$ Luciferin was injected and CCD images were taken of the mice after 6 weeks of regeneration. CCD (right top) and transillumination (TI) (right bottom) images were also taken of a representative graft at this stage. Mice were then castrated and reimaged at 7 weeks, with a representative graft harvested for CCD and TI imaging. Mice were then subjected to two rounds of androgen cycling with CCD images taken after each regrowth and involution.

\section{IDENTIFICATION AND ISOLATION OF THE PROSTATE STEM CELLS}

\section{Location}

Initial studies showed that after androgen was given back to castrated rodents, DNA synthesis was only observed at the tips of the prostatic tubules during regeneration, suggesting that the stem cells might be in the region of the tubule distal to the urethra (Sugimura et al. 1986). It was later determined that those cells with high proliferation activity were actually transient-amplifying progenitor cells (Cunha et al. 1987; Tsujimura et al. 2002). Many stem cells have been identified by label-retention experiments, which exploit their slow-cycling, quiescent nature (Cotsarelis et al. 1990; Hong et al. 2001; Duvillie et al. 2003). [ $\left.{ }^{3} \mathrm{H}\right]$ thymidine or bromodeoxyuridine (BrdU) is incorporated into the DNA of all cells and gets diluted out of faster-cycling cells while remaining concentrated in slow-cycling cells. Because the prostate does not regenerate and involute under physiological conditions, Tsujimura et al. (2002) used androgen cycling in combination with BrdU labeling to identify a population of slow-cycling cells in the basal layer of prostate tubules proximal to the urethra. To functionally confirm that stem cells are enriched in this area, these authors showed that cells in the proximal region have a higher proliferation potential in vitro and are more capable of regenerating prostatic tubules in the dissociated prostate regeneration assay through several passages (Goto et al. 2006). In addition, stem-cell-associated telomerase activity is higher in the proximal region of the rodent prostate anterior lobe (Banerjee et al. 1998).

\section{Isolation}

The ability to isolate stem cells from tissue is crucial for the in depth study of their biology and involvement in development and disease. Weissman and colleagues developed methods to purify the HSCs by FACS (fluorescence-activated cell sorting) to identify the short-term repopulating HSCs based on defined cell surface marker expression (Spangrude et al. 1988). Since then, populations enriched for stem cell activity have been isolated from many adult tissues using various magnetic bead and FACS techniques (Shackleton et al. 2006; Stingl et al. 2006; Corti et al. 2007). We and other investigators first identified the glycosyl phosphatidylinositol-anchored cell surface protein Sca-1 as a marker that can enrich for prostate stem cell activity, using magnetic bead sorting methods combined with in vitro and in vivo readout assays (Burger et al. 2005; Xin et al. 2005).

Sca-1 had previously been identified on stem cells of various tissues, including the mammary, liver, skeletal muscle, and heart (Spangrude et al. 1988; Welm et al. 2002; Kim et al. 2005). Sca-1-positive cells are approximately threefold enriched in the proximal region of the prostate, where the PrSCs are thought to reside (Xin et al. 2005). Sca-1-enriched cell populations have a significantly higher tubule-forming activity in the dissociated prostate cell regeneration assay. Furthermore, Wilson and colleagues have demonstrated that the Sca-1-positive 
cells from the proximal region had even higher regenerative activity than the Sca-1-positive cells from the intermediate and distal regions (Burger et al. 2005). Using 7AAD-staining, DNA-staining, and pyronin-Y RNAstaining techniques, we have shown that the Sca-1-positive cell fraction is enriched for quiescent cells, as defined by low RNA and DNA staining (Xin et al. 2005).

In 2003, three different groups looked for molecular signatures of "stemness" by comparing the microarray expression profiles of embryonic, neural, and hematopoietic stem cells (Ivanova et al. 2002; Ramalho-Santos et al. 2002; Fortunel et al. 2003). The three independent lists of genes had only one in common: integrin $\alpha_{6}$, also known as CD49f. A fraction of Sca-1-positive cells in the prostate express the stem cell markers CD49f and Bcl-2 (Burger et al. 2005; Lawson et al. 2007). Immunofluorescence analysis revealed that CD49f is strictly located on the basal surface of basal cells in the mouse prostate. Because Sca-1 is also present on some of the stromal and luminal cells, we predicted that combining this marker with CD49f would help to enrich for the basal cells of the proximal region. When the sphereforming activity of FACS-sorted Lin(Ter119, CD45, CD31) ${ }^{-}$Sca- $1^{+}$CD $49 f^{+}$(LSC) cells were compared to unfractionated prostate cells subjected to the same conditions, there was a 50-fold enrichment for growth activity. In fact, only these LSC cells possess sphere-forming and in vitro self-renewal activity, and only LSC cells could give rise to prostatic tubules in vivo (Fig. 4) (Lawson et al. 2007).

Although using the LSC antigenic profile greatly enriches for PrSCs, only 1 in 44 LSC cells actually has sphere-forming and stem cell activity. To better study the
PrSCs, our efforts have focused on purifying the stem cell population further. Microarray-based experiments comparing the expression profiles of the LSC and non-LSC epithelial populations have produced several new marker candidates that are under evaluation for additional enrichment potential.

\section{Human Prostate Stem Cells}

Approaches used to identify human PrSCs have included similar functional evaluation of surface-markerbased fractionated cells as well as dye-efflux-based studies. Collins et al. (2001) isolated a subpopulation of basal cells expressing high levels of integrin $\alpha_{2} \beta_{1}$, based on their rapid adhesion to type I collagen. These cells have higher colony-forming activity and a greater ability to regenerate prostate-like glands in vivo than other basal cells. CD133 (prominin-1), a hematopoietic and neural stem cell marker, was found to be strictly expressed in the integrin $\alpha_{2} \beta_{1}$ hi prostate cell fraction. The double-positive subpopulation has high in vitro growth activity as well as in vivo acinar structure regeneration potential, indicating that these markers enrich for stem cells (Richardson et al. 2004). The murine prostate stem cell marker CD49f has recently been found to also select for human prostate cells with high sphere-forming and self-renewal capabilities, which demonstrates that mouse and human stem cells share similarities (I. Garraway, unpubl.).

Several types of cancer cells and stem cells have been shown to express ATP-binding cassette (ABC) transporters associated with multidrug resistance. ABCG2 was
A
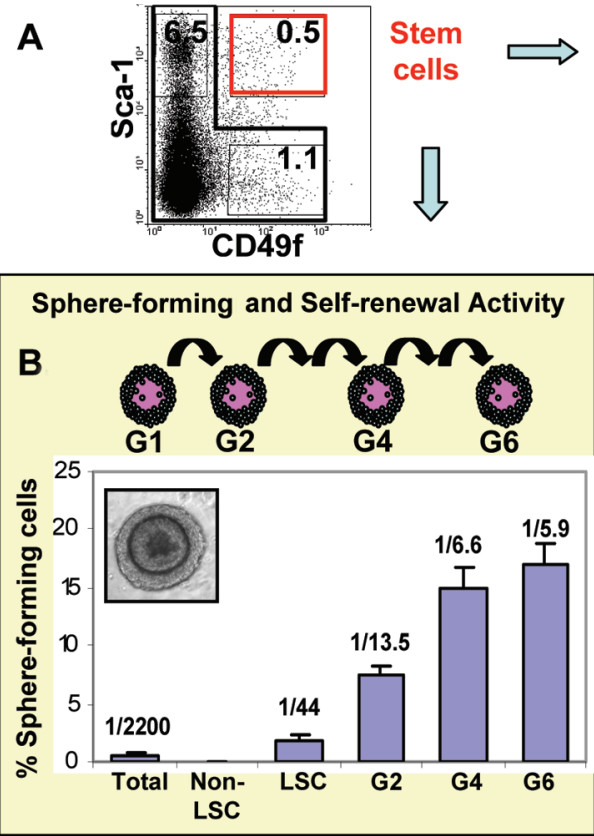

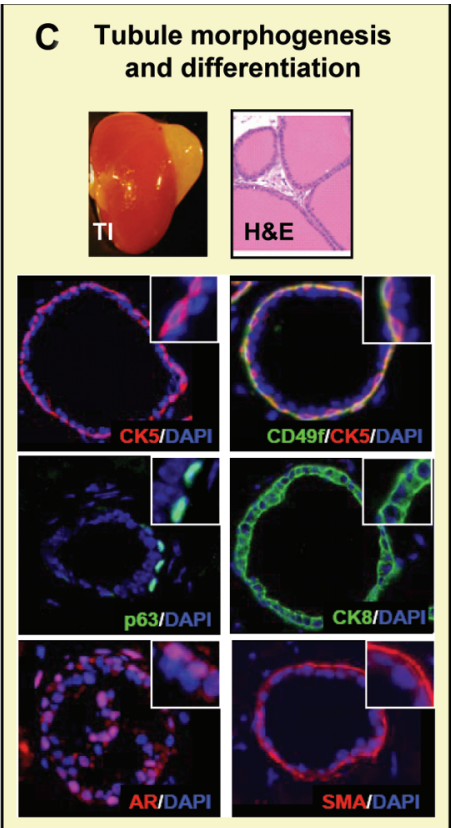

Figure 4. The LSC fraction enriches for stem-like activity. (A) FACS plot showing the LSC cell population (red box) and non-LSC cells of the prostate. $(B)$ Graph shows the outgrowth of spheres from the total prostate, non-LSC, and LSC populations, followed by sphere growth from the second, fourth, and sixth generation (G2, G4, G6) of passaged LSC-derived spheres. (C) Transillumination image (TI) of a kidney with regenerated tissue (top left) and hematoxylin and eosin (H\&E) stain of regenerated tubules (top right). Images show immunofluorescent staining of regenerated tubules for CK5, CD49f/CK5, p63, CK8, AR, and SMA. Sections are counterstained with DAPI. (Graph and stains reprinted, with permission, from Lawson et al. 2007 [C National Academy of Sciences].) 
shown to be efficient at Hoechst dye efflux, creating a side population (SP) phenotype that has been used as an alternate approach to identify multipotent stem cells in bone marrow, skeletal muscle, and neural tissue (Bunting 2002) and more recently in the prostate (Bhatt et al. 2003). The SP cells of the prostate have slightly higher sphere-forming activity in vitro than the non-SP cells, although only by fourfold (Brown et al. 2007). Further characterization showed that only $1 \%$ of the basal cells were included in the SP fraction, and they expressed known stem cell genes such as nestin, Bmi-1, hTeRT, and CD133 (Pascal et al. 2007). Although this evidence suggests that dye efflux methods have the potential to mark some primitive cells in the prostate and subdivide the basal fraction, these studies lack significant functional data.

\section{HUMAN PROSTATE CANCER AND PROSTATE CANCER MODELS}

Prostate cancer is predominantly a disease of aging, thought to progress in a step-like manner from prostatic intraepithelial neoplasia (PIN) lesions to local carcinoma and finally to metastatic disease. Many different genetic mutations have been identified in human prostate cancer over the years (Abate-Shen and Shen 2000). To recapitulate and study the disease, the most frequently found alterations have been used to create genetically engineered mouse models (Klein 2005). Our group has used the dissociated prostate regeneration assay for cancer studies, because a variety of individual or combinations of genetic alterations can be easily introduced into either the epithelial or mesenchymal compartment to drive transformation.

Alterations in the PTEN/AKT pathway are commonly seen in human prostate cancer as an activation of AKT or a loss of function in PTEN (Sun et al. 2001; Deocampo et al. 2003). Transgenic mice harboring a prostate-specific constitutively active AKT develop PIN lesions (Majumder et al. 2003), whereas conditional PTEN null mice develop prostate cancers that progress in a step-like fashion, as in the human disease (Wang et al. 2003; Ma et al. 2005). Using our regeneration assay, we also observe the growth of tubules containing PIN lesions upon the forced expression of myristoylated AKT1 and upon the inhibition of PTEN expression using short hairpin RNA (shRNA) (Xin et al. 2005). Alterations in androgen receptor signaling causing receptor hypersensitivity, promiscuity, or androgen-independent receptor trans-activation are also a common feature of prostate cancer (Feldman and Feldman 2001). When additional AR is introduced in addition to constitutively active AKT, regenerated grafts contain androgen-independent adenocarcinoma, resembling what is seen in the human disease (Xin et al. 2006).

Recently, there has been much excitement over Arul Chinnaiyan and colleagues' discovery of a class of translocations present in the majority of prostate cancers (Tomlins et al. 2005). This translocation is most commonly a result of the fusion of the androgen-responsive TMPRSS2 promoter and the coding region of the ETS family of transcription factors (ERG, ETV1, ETV4), which have previously been implicated in Ewing's sarcoma and other malignancies (Bohlander 2005; Kovar
2005). Other novel prostate-specific $5^{\prime}$ fusion partners have also been recently identified in prostate tumors with ETV1 outlier expression (Tomlins et al. 2007). Transgenic mice in which the overexpression of ERG is driven by the prostate-specific probasin promoter develop PIN lesions by 12-14 weeks of age (Tomlins et al. 2008). In recent experiments, we were able to recapitulate the PIN lesions seen in these transgenic mice by using lentivirus to introduce ERG1 into adult primary murine prostate cells and implanting these cells with UGSM under the kidney capsule of SCID (severe combined immunodeficiency disease) mice (Y. Zong, unpubl.).

Prostate cancer is unique in that it is often multifocal and heterogeneous, where several independent regions of the prostate display varying degrees of pathology. Heterogeneous genetic instability due to retroviral infection (Dong et al. 2007), perturbations in stroma, and "field effects" from global changes in the prostate (Harding and Theodorescu 2000) are three mechanisms by which this phenomenon can occur. Our dissociated prostate cellregeneration model is a useful tool to recapitulate the multifocal heterogeneity of prostate cancer. We recently demonstrated that forced overexpression of fibroblast growth factor-10 (FGF-10) in the mesenchyme can drive the transformation of epithelial cells, resulting in pockets of high-grade PIN and carcinoma (Memarzadeh et al. 2007). A subset of these epithelial cancer cells remain tumorigenic upon transplantation despite removal of high FGF-10-expressing stromal cells. Paracrine FGF-10 signaling also leads to an increase in epithelial androgen receptor levels, which can synergize with AKT to advance the pathology.

\section{THE CELL OF ORIGIN FOR PROSTATE CANCER}

Cell of origin studies are fueled by the theory that not all cells are equally susceptible to transformation. Initial attempts to identify the cell(s) of origin for prostate cancer consisted of marker expression analysis of tumor samples, which only introduced controversy in the field. Most prostate cancers are adenocarcinomas that express markers associated with luminal epithelial cells such as CK8, $\mathrm{AR}$, and prostate-specific antigen (PSA). Cells that express only basal markers such as CK5, CK14, and p63 are rarely observed in human cancers, leading to speculations that prostate cancer must initiate in a luminal progenitor or mature luminal cell that reacquired self-renewal (Nagle et al. 1987; Liu et al. 1999). Differentiated cells significantly outnumber primitive cells in all tissues. Therefore, the predominant presence of luminal cells in prostate cancer does not rule out a more immature cell as the original target for transformation.

Other studies have reported an expansion of intermediate cells in prostate cancer that coexpress both CK5 and CK8 (Verhagen et al. 1992). Reiter et al. (1998) have shown that a putative marker for late intermediate cells, PSCA, is often up-regulated in prostate cancer. These observations suggest that the disease may actually initiate in the transit-amplifying/intermediate progenitor cell population. An expansion of more primitive basal cells has also been observed in sev- 
eral cases. In the PTEN null mouse model where Cre deletes PTEN in both basal and luminal cells, there is a predominant expansion of the more primitive $\mathrm{p} 63^{+}$basal cells, suggesting that PTEN deletion-mediated prostate cancer begins in the more stem-like cells (Wang et al. 2003). In this model, as well as in our AKT1-driven carcinoma model, there is a dramatic expansion of the Sca-1-positive stem-like cells, further suggesting that these cells are the preferred targets for transformation. In our FGF-10 paracrine model for multifocal prostate cancer, we also observe a dramatic response and expansion in the CK5 and p63 ${ }^{+}$basal cells (Memarzadeh et al. 2007). All of these data suggest that the stem cell compartment can also serve as a responsive target for transformation.

One functional approach to identify the cell of origin is to control the expression of oncogenes or tumor suppressors by linking them to cell- or tissue-type-specific promoters in transgenic mice. When both p53 and RB (retinoblastoma) were conditionally knocked out in the prostate using probasin-driven $\mathrm{Cre}$, adenocarcinomas were only observed in the proximal region of the prostate (Zhou et al. 2007). In the tips of the tubules, where the intermediate and more differentiated cells reside, only areas of mild dysplasia were observed. This observation supports the idea that the differentiation status of the target cell probably dictates the severity of the transformation, largely due to their self-renewal capacity. In a separate study, DiGiovanni et al. (2000) described a prostate cancer model where mice express human insulinlike growth factor-1 (IGF-1) in the basal cell compartment, under the bovine CK5 promoter, and develop a stepwise disease progressing from hyperplasia, through PIN lesions, to adenocarcinoma, as in human disease. Because the oncogene was driven exclusively by the CK5 promoter, this result clearly suggests that basal cells can serve as targets for transformation.

Another approach is to sort out defined cell populations of a given organ and subject them to known oncogenes to compare their relative susceptibility for transformation. Huntly et al. (2004) used this technique to show that $B C R$ $A B L$ can only initiate chronic myelogenous leukemia (CML) in mice when expressed in HSCs and not in committed progenitors. In our initial attempts to investigate the tumor-forming capabilities of primitive and mature prostate cells, we compared the transforming capacity of Sca-1-positive and -negative cells after overexpressing AKT1 (Fig. 5) (Xin et al. 2005). Grafts from AKT- infected Sca-1-positive cells were ten times larger than the Sca-1-negative cell grafts. In addition, the Sca1-enriched grafts contained tubules with PIN lesions, whereas the grafts from the Sca-1-negative cells contained mostly normal looking tubules. These data suggest that cells capable of initiating cancer exist within the PrSC-enriched Sca-1 fraction.

Since these early studies, identification of the LSC fraction of prostate cells has enabled us to get a much higher enrichment of PrSCs. Using the LSC-staining profile, we can also identify and isolate the more differentiated luminal (progenitor) cells and the stromal cells of the prostate. We have recently compared the susceptibility of these newly enriched prostate cell fractions to transformation from Akt1 overexpression, PTEN deletion, ERG1 overexpression, and enhanced stromal FGF-10 signaling. In all of these cases, the stem-cell-enriched LSC fraction was the most responsive target. Our preliminary data suggest that the stem or progenitor cell fraction of the prostate is a preferred target for several different types of oncogenes.

Studies in leukemia have shown that some fusion oncogenes (MLL-ENL and MOZ-TIF2) are more successful than others $(B C R-A B L)$ at inducing transformation from committed myeloid progenitor cells, depending on their ability to confer self-renewal (Cozzio et al. 2003; Huntly et al. 2004). Several oncogenes and mutations found in prostate cancer, such as Bmi-1 and PTEN, have been linked to self-renewal (Stiles et al. 2004; Glinsky et al. 2005). One of our long-term goals is to test whether these specific oncogenes alone or in combination with others can induce transformation from prostate cells other than the stem cell fraction by inducing self-renewal.

\section{Cancer Stem Cells in Prostate Cancer}

Significant efforts have also been made to examine whether CSCs exist in prostate tumors and whether they are related to the PrSCs. Collins et al. (2005) isolated

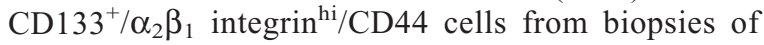
human tumors and showed that these cells had higher growth capacity and invasiveness in vitro than their marker-negative counterparts. It remains to be determined whether these cells are truly CSCs, because their tumorigenic activity was not tested in vivo. Cells with varying tumorigenic activity have been isolated from prostate cancer cell lines and xenografts using CD44
A

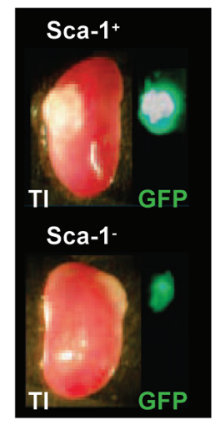

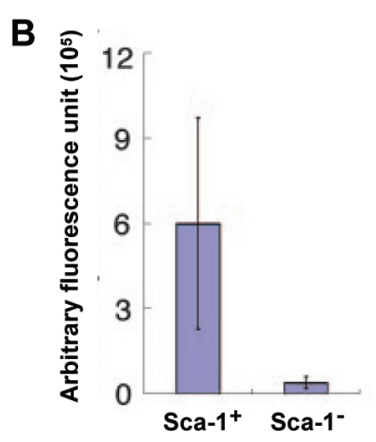

C

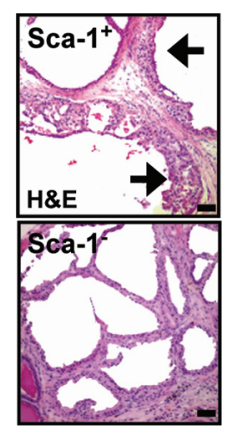

Figure 5. Prostate stem-cell-enriched fractions are efficient targets for transformation. (A) Transillumination (TI) and fluorescent (GFP) images of regenerated grafts from Sca- $1^{+}(t o p)$ and Sca- $1^{-}$ (bottom) cells infected with AKT-GFP lentivirus. (B) GFP fluorescent signals from the Sca-1-positive and -negative grafts were quantified. $(C)$ Hematoxylin and eosin (H\&E) staining of regenerated tissue from the AKT-infected Sca- $1^{+}$(top) and Sca- $1^{-}$(bottom) grafts. Arrows show areas of PIN lesion in the Sca- $1^{+}$grafts. (Reprinted, with permission, from Xin et al. 2005 [(C) National Academy of Sciences].) 
alone or in combination with the $\alpha_{2} \beta_{1}$ integrin $^{\text {hi }}$ profile, supporting the existence of a tumor cell hierarchy in the prostate (Patrawala et al. 2006, 2007). Although xenograft studies can be helpful, cell-line-based studies can be misleading due to cellular changes and selective pressures that can alter cancer cells in culture. Cells expressing embryonic stem cell (Oct4, Nanog, and Sox2) and early progenitor (CD44 and nestin) markers were found among immortalized primary human prostate cancer cells ( $\mathrm{Gu}$ et al. 2007). These cells could clonally reconstitute the original tumor in mice to contain all three prostate cell lineages, demonstrating some CSC properties. Interestingly, all of the markers associated with putative prostate cancer stem cells so far are also known PrSC markers. Traditional cancer stem cell studies must still be performed, comparing the in vivo tumor-initiating potential of different cell populations sorted from primary tumors to identify CSCs in prostate cancer.

\section{CONCLUSIONS}

Characterizing the prostate cells that are more susceptible to transformation and capable of cancer maintenance represents an essential step to a better understanding and more efficient treatment of the disease. Conventional therapeutics target and kill proliferating cells, sparing the putative cancer stem cell fraction and allowing for the recurrence of the disease in many cases. To be successful, therapy must not only kill the proliferating tumor cells, but also eliminate or differentiate the CSCs. Elucidating the molecular circuitry that contributes to the maintenance of normal prostate stem cells can provide key insight into the molecular mechanisms of these unique cancer cells.

Elimination of CSCs could be approached by targeting therapies against specific self-renewal pathways. Notch and Sonic Hedgehog (Shh) pathways have been previously found to have important roles in the maintenance of several types of tissue, including prostate (Beachy et al. 2004; Karhadkar et al. 2004; Wang et al. 2006). Modulation of the Shh pathway with cyclopamine has also been shown to decrease the growth of medulloblastoma (Romer et al. 2004) and prostate cancer (Karhadkar et al. 2004) in mouse models. Now that we have the ability to isolate a highly enriched PrSC fraction, our immediate goal is to identify novel pathways that confer long-term self-renewal to these cells and test whether their modulation can control the progression of prostate cancer. We have recently identified Bmi-1 as one such gene (R. Lukacs, unpubl.). Comparing the genetic expression profiles of tumorigenic cancer cells to normal PrSCs can aid in the identification of novel diagnostic markers and therapeutic targets that will spare the normal stem cells of the tissue. Alternatively, gaining a better understanding of the lineage hierarchy of the prostate and the mechanisms that control the differentiation process can reveal other potential targets with which differentiation of CSCs could be driven. The continual development of more precise and discriminative assays along with improvements in isolating highly purified stem cell fractions will be crucial for making progress in this field.

\section{ACKNOWLEDGMENTS}

We thank fellow lab members Stephanie Shelly and Houjin Cai for helpful suggestions. This work was supported by funds from the Prostate Cancer Foundation. O.N.W. is an investigator of the Howard Hughes Medical Institute. R.U.L. is supported by the California Institute for Regenerative Medicine training grant T1-00005. D.A.L was supported by the UCLA Graduate Student Dissertation Year fellowship grant. L.X. is supported by National Institutes of Health 1K99CA125937 Pathway to Independence. I.G. is supported by the Department of Defense Proposal (PC061088). S.M. has been supported by the NIH/National Cancer Institute, Clinical Scientist Training in Cancer Gene Medicine, K12-CA076905-09.

\section{REFERENCES}

Abate-Shen, C. and Shen, M.M. 2000. Molecular genetics of prostate cancer. Genes Dev. 14: 2410-2434.

Abrahamsson, P.A. 1999. Neuroendocrine differentiation in prostatic carcinoma. Prostate 39: 135-148.

Al-Hajj, M., Wicha, M.S., Benito-Hernandez, A., Morrison, S.J., and Clarke, M.F. 2003. Prospective identification of tumorigenic breast cancer cells. Proc. Natl. Acad. Sci. 100: 3983-3988.

Aumuller, G., Leonhardt, M., Janssen, M., Konrad, L., Bjartell, A., and Abrahamsson, P.A. 1999. Neurogenic origin of human prostate endocrine cells. Urology 53: 1041-1048.

Azuma, M., Hirao, A., Takubo, K., Hamaguchi, I., Kitamura, T., and Suda, T. 2005. A quantitative matrigel assay for assessing repopulating capacity of prostate stem cells. Biochem. Biophys. Res. Commun. 338: 1164-1170.

Banerjee, P.P., Banerjee, S., Zirkin, B.R., and Brown, T.R. 1998. Lobe-specific telomerase activity in the intact adult brown Norway rat prostate and its regional distribution within the prostatic ducts. Endocrinology 139: 513-519.

Beachy, P.A., Karhadkar, S.S., and Berman, D.M. 2004. Tissue repair and stem cell renewal in carcinogenesis. Nature 432: 324-331.

Bello-DeOcampo, D., Kleinman, H.K., Deocampo, N.D., and Webber, M.M. 2001. Laminin-1 and $\alpha 6 \beta 1$ integrin regulate acinar morphogenesis of normal and malignant human prostate epithelial cells. Prostate 46: 142-153.

Bhatt, R.I., Brown, M.D., Hart, C.A., Gilmore, P., Ramani, V.A., George, N.J., and Clarke, N.W. 2003. Novel method for the isolation and characterisation of the putative prostatic stem cell. Cytometry A 54: 89-99.

Blanpain, C., Horsley, V., and Fuchs, E. 2007. Epithelial stem cells: Turning over new leaves. Cell 128: 445-458.

Bohlander, S.K. 2005. ETV6: A versatile player in leukemogenesis. Semin. Cancer Biol. 15: 162-174.

Bonkhoff, H. 1998. Neuroendocrine cells in benign and malignant prostate tissue: Morphogenesis, proliferation, and androgen receptor status. Prostate Suppl. 8: 18-22.

Bonkhoff, H. and Remberger, K. 1996. Differentiation pathways and histogenetic aspects of normal and abnormal prostatic growth: A stem cell model. Prostate 28: 98-106.

Bonnet, D. and Dick, J.E. 1997. Human acute myeloid leukemia is organized as a hierarchy that originates from a primitive hematopoietic cell. Nat. Med. 3: 730-737.

Bradley, T.R. and Metcalf, D. 1966. The growth of mouse bone marrow cells in vitro. Aust. J. Exp. Biol. Med. Sci. 44: 287-299.

Brown, M.D., Gilmore, P.E., Hart, C.A., Samuel, J.D., Ramani, V.A., George, N.J., and Clarke, N.W. 2007. Characterization of benign and malignant prostate epithelial Hoechst 33342 side populations. Prostate 67: 1384-1396.

Bruce, W.R. and Van Der Gaag, H. 1963. A quantitative assay for the number of murine lymphoma cells capable of proliferation in vivo. Nature 199: 79-80. 
Bunting, K.D. 2002. ABC transporters as phenotypic markers and functional regulators of stem cells. Stem Cells 20: 11-20.

Burger, P.E., Xiong, X., Coetzee, S., Salm, S.N., Moscatelli, D., Goto, K., and Wilson, E.L. 2005. Sca-1 expression identifies stem cells in the proximal region of prostatic ducts with high capacity to reconstitute prostatic tissue. Proc. Natl. Acad. Sci. 102: $7180-7185$

Collins, A.T., Habib, F.K., Maitland, N.J., and Neal, D.E. 2001 Identification and isolation of human prostate epithelial stem cells based on $\alpha(2) \beta(1)$-integrin expression. J. Cell Sci. 114: 3865-3872.

Collins, A.T., Berry, P.A., Hyde, C., Stower, M.J., and Maitland, N.J. 2005. Prospective identification of tumorigenic prostate cancer stem cells. Cancer Res. 65: 10946-10951.

Corti, S., Nizzardo, M., Nardini, M., Donadoni, C., Locatelli, F., Papadimitriou, D., Salani, S., Del Bo, R., Ghezzi, S., Strazzer, S., et al. 2007. Isolation and characterization of murine neural stem/progenitor cells based on Prominin-1 expression. Exp. Neurol. 205: 547-562.

Cotsarelis, G., Sun, T.T., and Lavker, R.M. 1990. Label-retaining cells reside in the bulge area of pilosebaceous unit: Implications for follicular stem cells, hair cycle, and skin carcinogenesis. Cell 61: 1329-1337.

Cozzio, A., Passegue, E., Ayton, P.M., Karsunky, H., Cleary, M.L., and Weissman, I.L. 2003. Similar MLL-associated leukemias arising from self-renewing stem cells and shortlived myeloid progenitors. Genes Dev. 17: 3029-3035.

Cunha, G.R. and Lung, B. 1978. The possible influence of temporal factors in androgenic responsiveness of urogenital tissue recombinants from wild-type and androgen-insensitive (Tfm) mice. J. Exp. Zool. 205: 181-193.

Cunha, G.R., Donjacour, A.A., Cooke, P.S., Mee, S., Bigsby, R.M., Higgins, S.J., and Sugimura, Y. 1987. The endocrinology and developmental biology of the prostate. Endocr. Rev. 8: $338-362$.

Deocampo, N.D., Huang, H., and Tindall, D.J. 2003. The role of PTEN in the progression and survival of prostate cancer. Minerva Endocrinol. 28: 145-153.

DiGiovanni, J., Bol, D.K., Wilker, E., Beltran, L., Carbajal, S., Moats, S., Ramirez, A., Jorcano, J., and Kiguchi, K. 2000. Constitutive expression of insulin-like growth factor-1 in epidermal basal cells of transgenic mice leads to spontaneous tumor promotion. Cancer Res. 60: 1561-1570.

Dong, B., Kim, S., Hong, S., Das Gupta, J., Malathi, K., Klein, E.A., Ganem, D., Derisi, J.L., Chow, S.A., and Silverman, R.H. 2007. An infectious retrovirus susceptible to an IFN antiviral pathway from human prostate tumors. Proc. Natl. Acad. Sci. 104: 1655-1660.

Dontu, G., Abdallah, W.M., Foley, J.M., Jackson, K.W., Clarke, M.F., Kawamura, M.J., and Wicha, M.S. 2003. In vitro propagation and transcriptional profiling of human mammary stem/progenitor cells. Genes Dev. 17: 1253-1270.

Duvillie, B., Attali, M., Aiello, V., Quemeneur, E., and Scharfmann, R. 2003. Label-retaining cells in the rat pancreas: Location and differentiation potential in vitro. Diabetes 52: 2035-2042.

English, H.F., Santen, R.J., and Isaacs, J.T. 1987. Response of glandular versus basal rat ventral prostatic epithelial cells to androgen withdrawal and replacement. Prostate 11: 229-242.

Evans, G.S. and Chandler, J.A. 1987. Cell proliferation studies in the rat prostate. II. The effects of castration and androgeninduced regeneration upon basal and secretory cell proliferation. Prostate 11: 339-351.

Feldman, B.J. and Feldman, D. 2001. The development of androgen-independent prostate cancer. Nat. Rev. Cancer 1: 34-45.

Ford, C.E., Hamerton, J.L., Barnes, D.W., and Loutit, J.F. 1956. Cytological identification of radiation-chimaeras. Nature 177: 452-454.

Fortunel, N.O., Out, H.H., Ng, H.H., Chen, J., Mu, X., Chevassut, T., Li, X., Joseph, M., Bailey, C., Hatzfeld, J.A., et al. 2003. Comment on " 'Stemness': Transcriptional profiling of embryonic and adult stem cells" and "a stem cell molecular signature." Science 302: 393; author reply 393.

Glinsky, G.V., Berezovska, O., and Glinskii, A.B. 2005. Micro- array analysis identifies a death-from-cancer signature predicting therapy failure in patients with multiple types of cancer. J. Clin. Invest. 115: 1503-1521.

Goto, K., Salm, S.N., Coetzee, S., Xiong, X., Burger, P.E., Shapiro, E., Lepor, H., Moscatelli, D., and Wilson, E.L. 2006. Proximal prostatic stem cells are programmed to regenerate a proximal-distal ductal axis. Stem Cells 24: 1859-1868.

Gu, G., Yuan, J., Wills, M., and Kasper, S. 2007. Prostate cancer cells with stem cell characteristics reconstitute the original human tumor in vivo. Cancer Res. 67: 4807-4815.

Harding, M.A. and Theodorescu, D. 2000. Prostate tumor progression and prognosis. Interplay of tumor and host factors. Urol. Oncol. 5: 258-264.

Harrison, D.E. 1980. Competitive repopulation: A new assay for long-term stem cell functional capacity. Blood 55: 77-81.

Hewitt, H.B., Blake, E., and Proter, E.H. 1973. The effect of lethally irradiated cells on the transplantability of murine tumours. Br. J. Cancer 28: 123-135.

Hill, R.P. 2006. Identifying cancer stem cells in solid tumors: Case not proven. Cancer Res. 66: 1891-1895; discussion 1890.

Hong, K.U., Reynolds, S.D., Giangreco, A., Hurley, C.M., and Stripp, B.R. 2001. Clara cell secretory protein-expressing cells of the airway neuroepithelial body microenvironment include a label-retaining subset and are critical for epithelial renewal after progenitor cell depletion. Am. J. Respir. Cell Mol. Biology 24: 671-681.

Hudson, D.L., O'Hare, M., Watt, F.M., and Masters, J.R. 2000. Proliferative heterogeneity in the human prostate: Evidence for epithelial stem cells. Lab. Invest. 80: 1243-1250.

Hudson, D.L., Guy, A.T., Fry, P., O'Hare, M.J., Watt, F.M., and Masters, J.R. 2001. Epithelial cell differentiation pathways in the human prostate: Identification of intermediate phenotypes by keratin expression. J. Histochem. Cytochem. 49: 271-278.

Huggins, C. and Hodges, C. 1941. Studies on prostatic cancer. I. The effects of castration, of estrogen and of androgen injection on serum phosphatases in metastatic carcinoma of the prostate. Cancer Res. 1: 293-297.

Huntly, B.J., Shigematsu, H., Deguchi, K., Lee, B.H., Mizuno, S., Duclos, N., Rowan, R., Amaral, S., Curley, D., Williams, I.R., et al. 2004. MOZ-TIF2, but not BCR-ABL, confers properties of leukemic stem cells to committed murine hematopoietic progenitors. Cancer Cell 6: 587--596.

Isaacs, J.T. 1987. Control of cell proliferation and cell death in the normal and neoplastic prostate: A stem cell model. In Benign prostatic hyperplasia (ed. C.H. Rogers et al.), pp. 85-94. National Institutes of Health, Bethesda, Maryland.

Isaacs, J.T. and Coffey, D.S. 1989. Etiology and disease process of benign prostatic hyperplasia. Prostate 2: $33-50$.

Ivanova, N.B., Dimos, J.T., Schaniel, C., Hackney, J.A., Moore, K.A., and Lemischka, I.R. 2002. A stem cell molecular signature. Science 298: 601-604.

Jamieson, C.H., Ailles, L.E., Dylla, S.J., Muijtjens, M., Jones, C., Zehnder, J.L., Gotlib, J., Li, K., Manz, M.G., Keating, A., et al. 2004. Granulocyte-macrophage progenitors as candidate leukemic stem cells in blast-crisis CML. N. Engl. J. Med. 351: 657-667.

Karhadkar, S.S., Bova, G.S., Abdallah, N., Dhara, S., Gardner, D., Maitra, A., Isaacs, J.T., Berman D.M., and Beachy, P.A. 2004. Hedgehog signalling in prostate regeneration, neoplasia and metastasis. Nature 431: 707-712.

Kellokumpu-Lehtinen, P., Santti, R., and Pelliniemi, L.J. 1979. Early cytodifferentiation of human prostatic urethra and Leydig cells. Anat. Rec. 194: 429-443.

Kim, C.F., Jackson, E.L., Woolfenden, A.E., Lawrence, S., Babar, I., Vogel, S., Crowley, D., Bronson, R.T., and Jacks, T. 2005. Identification of bronchioalveolar stem cells in normal lung and lung cancer. Cell 121: 823-835.

Klein, R.D. 2005. The use of genetically engineered mouse models of prostate cancer for nutrition and cancer chemoprevention research. Mutat. Res. 576: 111-119.

Kordon, E.C. and Smith, G.H. 1998. An entire functional mammary gland may comprise the progeny from a single cell. Development 125: 1921-1930. 
Kovar H. 2005. Context matters: The hen or egg problem in Ewing's sarcoma. Semin. Cancer Biol. 15: 189-196.

Kyprianou, N. and Isaacs, J.T. 1988. Activation of programmed cell death in the rat ventral prostate after castration. Endocrinology 122: 552-562.

Lang, S.H., Sharrard, R.M., Stark, M., Villette, J.M., and Maitland, N.J. 2001. Prostate epithelial cell lines form spheroids with evidence of glandular differentiation in threedimensional Matrigel cultures. Br. J. Cancer 85: 590-599.

Lawson, D.A., Xin, L., Lukacs, R.U., Cheng, D., and Witte, O.N. 2007. Isolation and functional characterization of murine prostate stem cells. Proc. Natl. Acad. Sci. 104: 181-186.

Lemischka, I.R., Raulet, D.H., and Mulligan, R.C. 1986. Developmental potential and dynamic behavior of hematopoietic stem cells. Cell 45: 917-927.

Litvinov, I.V., De Marzo, A.M., and Isaacs, J.T. 2003. Is the Achilles' heel for prostate cancer therapy a gain of function in androgen receptor signaling? J. Clin. Endocrinol. Metab. 88: 2972-2982.

Liu, A.Y., True, L.D., LaTray, L., Ellis, W.J., Vessella, R.L., Lange, P.H., Higano, C.S., Hood, L., and van den Engh, G. 1999. Analysis and sorting of prostate cancer cell types by flow cytometry. Prostate 40: 192-199.

Lois, C. and Alvarez-Buylla, A. 1993. Proliferating subventricular zone cells in the adult mammalian forebrain can differentiate into neurons and glia. Proc. Natl. Acad. Sci. 90: 2074-2077.

Ma, X., Ziel-van der Made, A.C., Autar, B., van der Korput, H.A., Vermeij, M., van Duijn, P., Cleutjens, K.B., de Krijger, R., Krimpenfort, P., Berns, A. et al. 2005. Targeted biallelic inactivation of Pten in the mouse prostate leads to prostate cancer accompanied by increased epithelial cell proliferation but not by reduced apoptosis. Cancer Res. 65: 5730-5739.

Majumder, P.K., Yeh, J.J., George, D.J., Febbo, P.G., Kum, J., Xue, Q., Bikoff, R., Ma, H., Kantoff, P.W., Golub, T.R., et al. 2003. Prostate intraepithelial neoplasia induced by prostate restricted Akt activation: The MPAKT model. Proc. Natl. Acad. Sci. 100: 7841-7846.

McCulloch, E.A. and Till, J.E. 1960. The radiation sensitivity of normal mouse bone marrow cells, determined by quantitative marrow transplantation into irradiated mice. Radiat. Res. 13: $115-125$.

Memarzadeh, S., Xin, L., Mulholland, D.J., Mansukhani, A., Wu, H., Teitell, M.A., and Witte, O.N. 2007. Enhanced paracrine FGF10 expression promotes formation of multifocal prostate adenocarcinoma and an increase in epithelial androgen receptor. Cancer Cell 12: 572-585.

Nagle, R.B., Ahmann, F.R., McDaniel, K.M., Paquin, M.L., Clark, V.A., and Celniker, A. 1987. Cytokeratin characterization of human prostatic carcinoma and its derived cell lines. Cancer Res. 47: 281-286.

Pascal, L.E., Oudes, A.J., Petersen, T.W., Goo, Y.A., Walashek, L.S., True, L.D., and Liu, A.Y. 2007. Molecular and cellular characterization of ABCG2 in the prostate. BMC Urol. 7: 6.

Patrawala, L., Calhoun, T., Schneider-Broussard, R., Li, H., Bhatia, B., Tang, S., Reilly, J.G., Chandra, D., Zhou, J., Claypool, K., et al. 2006. Highly purified $\mathrm{CD} 44^{+}$prostate cancer cells from xenograft human tumors are enriched in tumorigenic and metastatic progenitor cells. Oncogene 25: 1696-1708

Patrawala, L., Calhoun-Davis, T., Schneider-Broussard, R., and Tang, D.G. 2007. Hierarchical organization of prostate cancer cells in xenograft tumors: the $\mathrm{CD} 44^{+} \alpha 2 \beta 1^{+}$cell population is enriched in tumor-initiating cells. Cancer Res. 67: 6796-6805.

Peters, L.J. and Hewitt, H.B. 1974. The influence of fibrin formation on the transplantability of murine tumour cells: Implications for the mechanism of the Revesz effect. $B r . J$. Cancer 29: 279-291.

Ploemacher, R.E., van der Sluijs, J.P., Voerman, J.S., and Brons, N.H. 1989. An in vitro limiting-dilution assay of long-term repopulating hematopoietic stem cells in the mouse. Blood 74: $2755-2763$
Ramalho-Santos, M., Yoon, S., Matsuzaki, Y., Mulligan, R.C., and Melton, D.A. 2002. "Stemness": Transcriptional profiling of embryonic and adult stem cells. Science 298: 597-600.

Reiter, R.E., Gu, Z., Watabe, T., Thomas, G., Szigeti, K., Davis, E., Wahl, M., Nisitani, S., Yamashiro, J., Le Beau, M.M., et al. 1998. Prostate stem cell antigen: A cell surface marker overexpressed in prostate cancer. Proc. Natl. Acad. Sci. 95: $1735-1740$.

Reya, T., Morrison, S.J., Clarke, M.F., and Weissman, I.L. 2001 Stem cells, cancer, and cancer stem cells. Nature 414: $105-111$.

Reynolds, B.A. and Weiss, S. 1996. Clonal and population analyses demonstrate that an EGF-responsive mammalian embryonic CNS precursor is a stem cell. Dev. Biol. 175: 1-13.

Richardson, G.D., Robson, C.N., Lang, S.H., Neal, D.E., Maitland, N.J., and Collins, A.T. 2004. CD133, a novel marker for human prostatic epithelial stem cells. J. Cell Sci. 117: 3539-3545.

Romer, J.T., Kimura, H., Magdaleno, S., Sasai, K., Fuller, C., Baines, H., Connelly, M., Stewart, C.F., Gould, S., Rubin, L.L., et al. 2004. Suppression of the Shh pathway using a small molecule inhibitor eliminates medulloblastoma in Ptcl $^{+/-} p 53^{-1-}$ mice. Cancer Cell 6: 229-240.

Shackleton, M., Vaillant, F., Simpson, K.J., Stingl, J., Smyth, G.K., Asselin-Labat, M.L., Wu, L., Lindeman, G.J., and Visvader, J.E. 2006. Generation of a functional mammary gland from a single stem cell. Nature 439: $84-88$.

Shi, X., Gipp, J., and Bushman, W. 2007. Anchorage-independent culture maintains prostate stem cells. Dev. Biol. 312: 396-406.

Singh, S.K., Hawkins, C., Clarke, I.D., Squire, J.A., Bayani, J., Hide, T., Henkelman, R.M., Cusimano, M.D., and Dirks, P.B. 2004. Identification of human brain tumour initiating cells. Nature 432: 396-401.

Southam, C.M., Burchenal, J.H., Clarkson, B., Tanzi, A., Mackey, R., and McComb, V. 1969. Heterotransplantability of human cell lines derived from leukemia and lymphomas into immunologically tolerant rats. Cancer 24: 211-222.

Spangrude, G.J., Heimfeld, S., and Weissman, I.L. 1988 Purification and characterization of mouse hematopoietic stem cells. Science 241: 58-62.

Stiles, B., Groszer, M., Wang, S., Jiao, J., and Wu, H. 2004. PTENless means more. Dev. Biol. 273: 175-184.

Stingl, J., Eirew, P., Ricketson, I., Shackleton, M., Vaillant, F. Choi, D., Li, H.I., and Eaves, C.J. 2006. Purification and unique properties of mammary epithelial stem cells. Nature 439: 993-997.

Sugimura, Y., Cunha, G.R., and Donjacour, A.A. 1986. Morphogenesis of ductal networks in the mouse prostate. Biol. Reprod. 34: 961-971.

Sun, M., Wang, G., Paciga, J.E., Feldman, R.I., Yuan, Z.Q., Ma, X.L., Shelley, S.A., Jove, R., Tsichlis, P.N., Nicosia, S.V., et al. 2001. AKT1/PKB $\alpha$ kinase is frequently elevated in human cancers and its constitutive activation is required for oncogenic transformation in NIH3T3 cells. Am. J. Pathol. 159: 431-437.

Till, J.E. and McCulloch, E. 1961. A direct measurement of the radiation sensitivity of normal mouse bone marrow cells. Radiat. Res. 14: 213-222.

Tomlins, S.A., Rhodes, D.R., Perner, S., Dhanasekaran, S.M., Mehra, R., Sun, X.W., Varambally, S., Cao, X., Tchinda, J., Kuefer, R., et al. 2005. Recurrent fusion of TMPRSS2 and ETS transcription factor genes in prostate cancer. Science 310: 644-648.

Tomlins, S.A., Laxman, B., Dhanasekaran, S.M., Helgeson, B.E., Cao, X., Morris, D.S., Menon, A., Jing, X., Cao, Q., Han, B., et al. 2007. Distinct classes of chromosomal rearrangements create oncogenic ETS gene fusions in prostate cancer. Nature 448: 595-599.

Tomlins, S.A., Laxman, B., Varambally, S., Cao, X., Yu, J., Helgeson, B.E., Cao, Q., Prensner, J.R., Rubin, M.A., Shah, R.B., et al. 2008. Role of the TMPRSS2-ERG gene fusion in prostate cancer. Neoplasia 10: 177-188.

Tran, C.P., Lin, C., Yamashiro, J., and Reiter, R.E. 2002. 
Prostate stem cell antigen is a marker of late intermediate prostate epithelial cells. Mol. Cancer Res. 1: 113-121.

Tsujimura, A., Koikawa, Y., Salm, S., Takao, T., Coetzee, S., Moscatelli, D., Shapiro, E., Lepor, H., Sun, T.T., and Wilson, E.L. 2002. Proximal location of mouse prostate epithelial stem cells: A model of prostatic homeostasis. J. Cell Biol. 157: $1257-1265$.

Uzgare, A.R., Xu, Y., and Isaacs, J.T. 2004. In vitro culturing and characteristics of transit amplifying epithelial cells from human prostate tissue. J. Cell Biochem. 91: 196-205.

Verhagen, A.P., Ramaekers, F.C., Aalders, T.W., Schaafsma, H.E., Debruyne, F.M., and Schalken, J.A. 1992. Colocalization of basal and luminal cell-type cytokeratins in human prostate cancer. Cancer Res. 52: 6182-6187.

Virchow, R. 1855. Editorial. In Archiv fuer pathologisce anatomie und physiologie und klinische medizin, p. 23.

Wang, Y., Hayward, S., Cao, M., Thayer, K., and Cunha, G. 2001. Cell differentiation lineage in the prostate. Differentiation 68: 270-279.

Wang, S., Gao, J., Lei, Q., Rozengurt, N., Pritchard, C., Jiao, J., Thomas, G.V., Li, G., Roy-Burman, P., Nelson, P.S., et al. 2003. Prostate-specific deletion of the murine Pten tumor suppressor gene leads to metastatic prostate cancer. Cancer Cell 4: 209-221.

Wang, X.D., Leow, C.C., Zha, J., Tang, Z., Modrusan, Z., Radtke, F., Aguet, M., de Sauvage, F.J., and Gao, W.Q. 2006. Notch signaling is required for normal prostatic epithelial cell proliferation and differentiation. Dev. Biol. 290: 66-80.

Webber, M.M., Bello, D., Kleinman, H.K., and Hoffman, M.P. 1997. Acinar differentiation by non-malignant immortalized human prostatic epithelial cells and its loss by malignant cells. Carcinogenesis 18: 1225-1231.

Welm, B.E., Tepera, S.B., Venezia, T., Graubert, T.A., Rosen,
J.M., and Goodell, M.A. 2002. Sca- ${ }^{\text {pos }}$ cells in the mouse mammary gland represent an enriched progenitor cell population. Dev. Biol. 245: 42-56.

Wernert, N., Seitz, G., and Achtstatter, T. 1987. Immunohistochemical investigation of different cytokeratins and vimentin in the prostate from the fetal period up to adulthood and in prostate carcinoma. Pathol. Res. Pract. 182: 617-626.

Wicha, M.S., Liu, S., and Dontu, G. 2006. Cancer stem cells: An old idea-A paradigm shift. Cancer Res. 66: 1883-1890; discussion 1895-1896.

Xie, X., Luo, Z., Slawin, K.M., and Spencer, D.M. 2004. The EZC-prostate model: Noninvasive prostate imaging in living mice. Mol. Endocrinol. 18: 722-732.

Xin, L., Ide, H., Kim, Y., Dubey, P., and Witte, O.N. 2003. In vivo regeneration of murine prostate from dissociated cell populations of postnatal epithelia and urogenital sinus mesenchyme. Proc. Natl. Acad. Sci. (suppl. 1) 100: 11896-11903.

Xin, L., Lawson, D.A., and Witte, O.N. 2005. The Sca-1 cell surface marker enriches for a prostate-regenerating cell subpopulation that can initiate prostate tumorigenesis. Proc. Natl. Acad. Sci. 102: 6942-6947.

Xin, L., Teitell, M.A., Lawson, D.A., Kwon, A., Mellinghoff, I.K., and Witte, O.N. 2006. Progression of prostate cancer by synergy of AKT with genotropic and nongenotropic actions of the androgen receptor. Proc. Natl. Acad. Sci. 103: 7789-7794.

Xin, L., Lukacs, R.U., Lawson, D.A., Cheng, D., and Witte, O.N. 2007. Self-renewal and multilineage differentiation in vitro from murine prostate stem cells. Stem Cells 25: 2760-2769.

Zhou, Z., Flesken-Nikitin, A., and Nikitin, A.Y. 2007. Prostate cancer associated with $\mathrm{p} 53$ and $\mathrm{Rb}$ deficiency arises from the stem/progenitor cell-enriched proximal region of prostatic ducts. Cancer Res. 67: 5683-5690. 


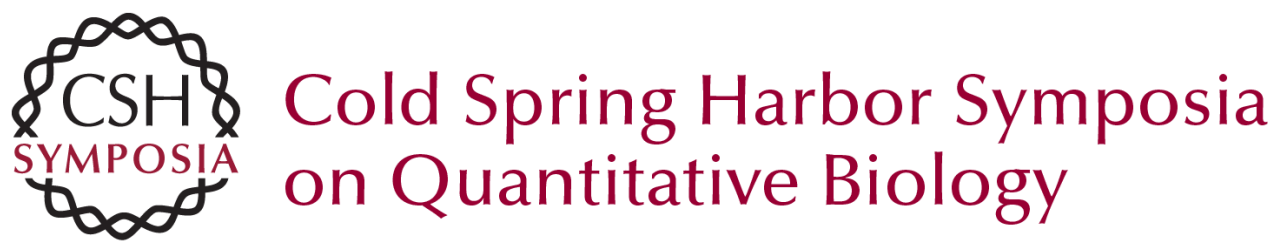

\section{Epithelial Stem Cells of the Prostate and Their Role in Cancer Progression}

R.U. Lukacs, D.A. Lawson, L. Xin, et al.

Cold Spring Harb Symp Quant Biol 2008 73: 491-502 originally published online November 6, 2008 Access the most recent version at doi:10.1101/sqb.2008.73.012

References This article cites 110 articles, 36 of which can be accessed free at: http://symposium.cshlp.org/content/73/491.full.html\#ref-list-1

\section{License}

Email Alerting Receive free email alerts when new articles cite this article - sign up in the Service box at the top right corner of the article or click here. 